\title{
A study of maternal mortality in a tertiary care hospital
}

\author{
Usha Doddamani*, Nirmala Rampure, Kaveri, Pooja
}

Department of Obstetrics and Gynecology, Gulbarga Institute of Medical Sciences, Kalaburgi, Karnataka, India

Received: 14 April 2018

Accepted: 08 May 2018

\section{*Correspondence:}

Dr. Usha Doddamani,

E-mail: dr.ushadoddamani@gmail.com

Copyright: (c) the author(s), publisher and licensee Medip Academy. This is an open-access article distributed under the terms of the Creative Commons Attribution Non-Commercial License, which permits unrestricted non-commercial use, distribution, and reproduction in any medium, provided the original work is properly cited.

\section{ABSTRACT}

Background: Maternal mortality is a strong indicator for measuring the health care provided to the women by any society. Motherhood is an event of joy and celebrations for every family. It is tragic that deaths occur during pregnancy and childbirth and most are preventable. The aim is to study the incidence of maternal mortality, assess the epidemiological aspects, causes of maternal mortality and avoidable factors that can prevent maternal deaths.

Methods: A retrospective hospital based study was conducted in the Department of OBG, Gulbarga Institute of Medical Sciences, a tertiary level health care referral centre in Kalaburgi, Karnataka, India over a period of 2 years from January, 2016 to December, 2017.

Results: A total of 65 deaths were analysed. The mortality rate in study period was 364 per 1,00,000 live births. Maximum maternal deaths were reported in the age group 20-24 years. More deaths were reported in multiparous women $(55.8 \%)$ as compared to primiparous women $(44.2 \%)$. Most of them were unbooked cases $(60 \%)$. The classic triad of haemorrhage (38.4\%), hypertensive disorders $(29.2 \%)$ and sepsis $(12 \%)$ were the major direct causes of maternal death. Anemia was the major indirect cause of death. Other indirect causes of maternal death were jaundice, heart disease, respiratory disease and epilepsy.

Conclusions: Majority of maternal deaths were preventable by proper antenatal care, early detection of high risk pregnancies and their timely referral to tertiary care centre.

Keywords: Anaemia, Haemorrhage, Hypertensive disorders, Maternal mortality, Sepsis

\section{INTRODUCTION}

Maternal mortality is an indicator of the quality of obstetric care in a community directly reflecting the utilization of health care services available. ${ }^{1}$ Maternal mortality is defined as the death of a woman while being pregnant or within 42 completed days of termination of pregnancy, irrespective of the duration or site of pregnancy, from any cause related to or aggravated by pregnancy, but not from accidental or incidental causes. ${ }^{2}$ Maternal mortality is defined internationally as maternal death rate per 1,00,000 live births. There are about 880 maternal deaths every day. Most of these occur in low resource settings and can be prevented. Seeing this, countries have united to reduce the global maternal mortality ratio to $<70 / 1,00,000$ live births between 2016 and 2030 as a part of the Sustainable Development Agenda. $^{3}$

In 2012 MMR (maternal mortality ratio) of India was 178 , which is much above the objective of 109 as per the MDG. ${ }^{4}$ The fifth millennium development goal (MDG) initially articulated on target: "to reduce maternal mortality ratio (MMR) by three quarters by $2015 .{ }^{5}$ Low status of the women in the society coupled with low literacy rates also leads to underutilization of available health services. A respectable number of maternal deaths 
can be averted by skilled care before, during and after childbirth. ${ }^{6}$

This study was conducted at the Department of Obstetrics and Gynecology, Gulbarga institute of Medical Sciences, Kalaburgi, Karnataka with an aim to analyse the causes, risk factors associated with maternal mortality and avoidable factors that can prevent maternal death.

\section{METHODS}

This was a retrospective study of 65 cases of maternal deaths over a period of 2 years from JAN 2016 to DEC 2017. All booked or unbooked maternal deaths admitted at the time of pregnancy, delivery or during puerperium were included in study. The data was collected from hospital records. The medical records sheets of all identified women were reviewed regarding age, parity, residence, antenatal booking status and cause of maternal death. Data was collected on a proforma and entered into computer using SPSS version 10 for analysis. Permission of the institutional ethical committee was obtained before recording data on proforma with the assurance of its confidentiality. Causes of death were identified as direct cause and indirect cause.

\section{RESULTS}

During the study period January 2016 to December 2017 there were a total of 17,820 live births and 65 maternal deaths. The MMR in the study period was 364 per 1,00,000 live births. The epidemiological characteristics of maternal death are shown in Table 1 .

Table 1: Demographic characteristics of maternal deaths.

\begin{tabular}{|c|c|c|c|}
\hline $\begin{array}{l}\text { Pt } \\
\text { characteristics }\end{array}$ & Classification & $\begin{array}{l}\text { No. of } \\
\text { cases }\end{array}$ & Percent \\
\hline \multirow{5}{*}{ Age } & $<20$ & 4 & 6.2 \\
\hline & $20-24$ & 32 & 49.2 \\
\hline & $25-29$ & 16 & 24.6 \\
\hline & $30-34$ & 7 & 10.7 \\
\hline & $>34$ & 6 & 9.3 \\
\hline \multirow{3}{*}{ Parity } & Primi & 29 & 44.2 \\
\hline & Multigravidae & 25 & 38.4 \\
\hline & Grandmulti & 11 & 17.4 \\
\hline \multirow{2}{*}{ Residence } & Rural & 54 & 83 \\
\hline & Urban & 11 & 17 \\
\hline \multirow{2}{*}{$\begin{array}{l}\text { Antenatal } \\
\text { status }\end{array}$} & Booked & 26 & 40 \\
\hline & Unbooked & 39 & 60 \\
\hline
\end{tabular}

Maximum maternal deaths were reported in the age group 20 - 24 years $(49.2 \%)$. Death among teenage pregnancies were seen in $6.2 \%$ of cases. Regarding parity majority of deaths were seen in multiparous women $(55.8 \%)$ as compared to primiparous women $(44.2 \%)$. $60 \%$ of cases were unbooked. More maternal deaths were reported in women from rural areas $(83 \%)$.

The classic triad of haemorrhage, hypertensive disorders and sepsis were the major causes of maternal death. In our study haemorrhage was the leading cause of maternal death followed by hypertensive disorders seen in $29.2 \%$ of cases. Sepsis was seen in $12 \%$ of cases. Rupture uterus and pulmonary embolism were other direct causes of maternal death. Anemia was the major indirect cause and significant comorbid factor of maternal death. The other indirect causes of maternal death were jaundice, heart disease, respiratory disease and epilepsy (Table 2).

Table 2: Causes of Maternal deaths.

\begin{tabular}{|lll|}
\hline Cause & Number & Percentage \\
\hline Haemorrhage & 25 & 38.4 \\
\hline Hypertensive disorder & 19 & 29.2 \\
\hline Sepsis & 8 & 12.0 \\
\hline Rupture uterus & 2 & 3.0 \\
\hline Pulmonary embolism & 4 & 6.1 \\
\hline Jaundice & 1 & 1.5 \\
\hline Heart disease & 2 & 3.0 \\
\hline Respiratory disorder & 3 & 4.6 \\
\hline Epilepsy & 1 & 1.5 \\
\hline
\end{tabular}

\section{DISCUSSION}

Maternal mortality is a global health problem. According to estimates by the United Nations, at current levels of fertility and mortality, 1 in 190 women in India face the risk of maternal mortality compared with 1 in 170 in Pakistan and 1 in 1400 in Sri Lanka. ${ }^{7}$ Recently UNICEF has estimated that approximately $80 \%$ of maternal death could be averted if women had access to essential maternity and basic health care services. ${ }^{8}$

The maternal mortality ratio (MMR) in our study is 364 per 1,00,000 live births which is very much higher than national standards of MMR in India that is 212 per $1,00,000$ live births. ${ }^{9}$ Present study has comparatively higher MMR which could be due to the fact that our hospital is a tertiary care hospital and receives a lot of complicated referrals from rural areas. In a study by Tayade et al reported an MMR of 242 at Wadgwa, Maharashtra where as Shivkumar et al reported MMR of 974 at VIMS Bellary, Karnataka. ${ }^{10,11}$

Most mothers died in the age group 20-24 years (49.2\%). Majority of them were unbooked (60\%) and multigravidae $(55.8 \%)$. In present study demographic characteristics of maternal death were comparable to Pathak et al and Sashikala Mootha. ${ }^{12,13}$ In present study haemorrhage was the leading cause of maternal death followed by hypertensive disorders and sepsis (Table 3). ${ }^{13-16}$ Even today large number of maternal deaths were due to classic triad of haemorrhage, hypertensive disorders and sepsis. The indirect causes of maternal 
death were jaundice, heart disease, respiratory disorders and epilepsy. Anemia was the significant comorbid factor in our study which is comparable to study done by Paul et al. ${ }^{17}$

Table 3: Comparison of causes of maternal death by various authors.

\begin{tabular}{|lllc|}
\hline Authors & Haemorrhage & $\begin{array}{l}\text { Hypertensive } \\
\text { disorder }\end{array}$ & Sepsis \\
\hline $\begin{array}{l}\text { Mootha S } \\
\text { et al }\end{array}$ & 28.9 & 47.9 & 23.4 \\
\hline $\begin{array}{l}\text { Vidhyadhar B } \\
\text { et al }\end{array}$ & 21.5 & 10.5 & 7.8 \\
\hline $\begin{array}{l}\text { Soni M } \\
\text { et al }\end{array}$ & 29.5 & 12.9 & 18.0 \\
\hline $\begin{array}{l}\text { Sundari KPM } \\
\text { et al }\end{array}$ & 17.8 & 26.7 & 12.5 \\
\hline
\end{tabular}

\section{CONCLUSION}

A number of sociodemographic factors affect maternal mortality. It was observed that poor, illiterate, unbooked women coming from remote rural areas were more vulnerable to morbidity and mortality. Haemorrhage is the leading cause of maternal death followed by hypertensive disorders and sepsis. Anemia continues to be the most common indirect cause. Death due to haemorrhage can be controlled by SBA training of all nursing staff. Death due to hypertensive disorders can be reduced by early identification of PIH, use of Magnesium sulphate and early termination of eclampsia. The need for antibiotics and infection control practices are to be strictly followed to reduce death due to sepsis. Early correction of anemia and health education on importance of IFA tablets will reduce death due to anemia. Lastly most deaths could have been prevented with the help of early referral, quick efficient transport facilities, availability of blood and by promoting overall safe motherhood.

\section{ACKNOWLEDGMENTS}

Authors would like to thank colleagues of Department of OBG and clerical staff of Medical Records Department for their support during study.

Funding: No funding sources Conflict of interest: None declared

Ethical approval: The study was approved by the Institutional Ethics Committee

\section{REFERENCES}

1. Juneja Y, Rai U. A five years review of maternal mortality. J Obstet Gynecol India. 1993;43:944-9.
2. Park K. Preventive medicine in obstetric, paediatric and geriatrics: Park's Text Book of Preventive and Social Medicine. 20 ${ }^{\text {th }}$ edition. Jabalpur: M/S Banarasi Das Bhanot; 2009;479-483.

3. WHO: Maternal Mortality Factsheet Available at http://www.who.int/mediacentre/factsheets/fs348/en

4. Sample Registration System, Office of Registrar General, India. Special bulletin on maternal mortality in India 2010-12, December 2013. Available at http://www.censusindia.gov.in/vital_statistics/SRS_Bull etins/MMR_Bulletin-2010-12

5. Abdella A. Maternal mortality trend in Ethiopia. Ethiop J Health Dev 2010;24(1):115-22.

6. Say L, Chou D, Gemmil A, Tuncalp O, Moller AB, Daniel J, et al. Global causes of maternal death: A WHO systematic analysis. Lancet Glob Health. 2014;2:e323-33.

7. WHO Trends in maternal mortality, 1990-2013. WHO, UNICEF, UNFPA. The World Bank and The United Nations Population Division Estimates,2014. Available at

http://apps.who.int/iris/bitstream/10665/112682/2/9789 241507226_eng.pdf.

8. UNICEF. The state of the world's children 2009: maternal and newborn health. In: UNICEF, eds. Sales No. E 09.xx.1. India: United Nations Publications; 2010:2.

9. Special Bulletin on Maternal Mortality in India 200709: Sample registration system, Office of Registrar General, India; June 2011.

10. Tayade S, Bagde M, Shivkumar PV, Tayade A, Bagde $\mathrm{N}$. Maternal death review to know the determinants of maternal mortality in a district hospital of central India. Int J Biomed Res. 2012; 3(03):157-63.

11. Shivkumar HC, Umashankar KM, Ramaraju HE, Shankar J.Analysis of maternal mortality in tertiary care hospital, Vijayanagara institute of medical sciences, Bellary, South India. Int J Basic Appl Medn Sci. 2013;3(2):237-42.

12. Pathak D, Chakraborty B, Goswami S, Adhikari S. Changing trends in maternal mortality: A comparative study. J of Obstet and Gynecol India. 2011;61(2):161-5.

13. Shashikala M, Usharani B. Evaluation of maternal mortality rate at a high volume tertiary referral centre: what are we missing. A study spanning 85,404 live births over 9 years. Int J of Sci and Res. 2015;4(1):3023.

14. Vidhyadhar B, Purushottam A, Giri B, Garg RC. Maternal mortality at a tertiary care teaching hospital of rural India, a retrospective study. Int J Biol Med Res. 2011;2(4):1043 -6.

15. Monica S, Priyanka SG, Ankur G. Causes of maternal mortality and changing trends: A retrospective analysis. Int J of Sci Study. 2016;4:(7):105-7.

16. Sundari KPM, Jayanti RD, Ramaswamy B. Trends in a tertiary care hospital. Int J of Reprod Contracept Obstet Gynecol. 2016;5(11):3659-62.

Cite this article as: Doddamani U, Rampure N, Kaveri, Pooja. A study of maternal mortality in a tertiary care hospital. Int J Reprod Contracept Obstet Gynecol 2018;7:2446-8. 